\title{
Science Literacy Profile of Junior High School Students Based on Knowledge, Competence, Cognitive, and Context Aspects
}

\author{
Yohana Saraswati ${ }^{1}$, Sifak Indana ${ }^{2}$, Elok Sudibyo
}

1,2,3 State University of Surabaya, Surabaya, Indonesia

\begin{tabular}{|c|c|}
\hline A) Check for updates open $\partial_{\text {access }}$ (c) (1) (2) & DOI : https://doi.org/10.46245/ijorer.v2i3.118 \\
\hline Sections Info & ABSTRACT \\
\hline & \multirow{12}{*}{$\begin{array}{l}\text { Humans are faced with industrial advances based on science and technology } \\
\text { to meet the needs of human life and solve problems from related issues based } \\
\text { on scientific literacy skills. This study aims to describe students' scientific } \\
\text { literacy skills which include aspects of knowledge, aspects of competence, } \\
\text { aspects of cognitive, and aspects of the context of junior high school students } \\
\text { aged } 15 \text { years. This research is a quantitative descriptive analysis research. The } \\
\text { instrument used to determine scientific literacy skills was a scientific literacy } \\
\text { test consisting of } 20 \text { multiple choice questions. The science literacy test was } \\
\text { validated by two expert lecturers at the State University of Surabaya and one } \\
\text { science teacher at State Junior High School of } 32 \text { Surabaya. The research also } \\
\text { aims to describe the correlation of scientific attitudes to scientific literacy } \\
\text { skills. The instrument used was a response questionnaire with } 20 \text { yes and no } \\
\text { questions. The results showed that the value of the knowledge aspect was } \\
60.57 \% \text {, the competency aspect was } 60.60 \% \text {, the cognitive aspect was } 59.9 \% \text {, } \\
\text { and the context aspect was } 60.19 \% \text {. Scientific literacy skills can be improved by } \\
\text { refraction,strategies, and appropriate learning methods. Teachers need to } \\
\text { provide access to learning resources from various literary sources, including } \\
\text { browsing information via the internet. Students need to be trained to be } \\
\text { literate, hone critical and creative thinking, be competent in making decisions } \\
\text { to solve problems, and communicate systematically. }\end{array}$} \\
\hline & \\
\hline 2021 & \\
\hline & \\
\hline & \\
\hline & \\
\hline & \\
\hline & \\
\hline & \\
\hline & \\
\hline & \\
\hline 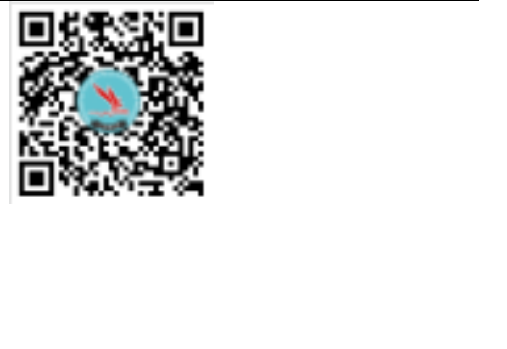 & \\
\hline
\end{tabular}

\section{INTRODUCTION}

Malik (2018) stated, "In the 21st century, we live in an interconnected world where globalization, Information Communication Technology and knowledge explosion have shrunk the world into a global village. Education, ICT, innovation and science technology are the main pillars of knowledge society. Technology is shaking the world ". In other words, In 21st century is a century where industrial progress develops based on science and technology which aims to meet the needs of human life. The developing industry cannot be separated from investigative activities. Investigative activities are in the form of making observations, formulating problems, conducting analyzes, making conclusions and providing recommendations, communicating the results of experiments in writing and presentations (Aberšek, 2015). Investigation activities cannot be separated from the educational aspect.

Based on the global competitiveness index from The Global Competitiveness Report 2012-2013 published by the World Economic Forum (WEF), Indonesia ranks 50th out of 144 countries in 2012 at the world level, 46th out of 142 countries in 2011 and 44 in 2010 (Irianti, 2019). This condition was exacerbated by the achievement of scientific literacy reported by the 2018 PISA (Program for International Student Assessment) announced by the OECD (The Organization for Economic Co-operation and Development) which showed an average score of 489 scientific literacy, while Indonesia's score was 396 with 
a ranking 70 out of 78 countries (OECD, 2018). So it can be concluded that the quality of education in Indonesia is currently low compared to other developed countries.

Scientific literacy is the ability of individual scientific knowledge to identify phenomena, explain, and draw conclusions about issues related to science; understand science as a science of inquiry; prove that science shapes nature; and is actively involved in solving science-related problems (Archer, 2014). Scientific literacy is kthe ability to interact with various aspects in a consistent manner based on the values that underlie science (Laugksch, 2017). Pscience lessons will be meaningful if students are taught to understand science concepts through direct experience and connect with concepts and problems contextually (Jampel, 2018).

Science education in Indonesia has been implemented for many years, but the literacy results obtained from PISA are still very low. The low value is because the teaching and learning process focuses on mastering theory, memorization, and evaluation instruments which do not provide literacy experiences, so students cannot interpret the science learning process. The reading, numeracy, and science literacy abilities of Indonesian students can be analyzed through the PISA results (Argina, 2017).

One of the targets of science education is scientific literacy (Widowati, 2017). One of the goals of scientific literacy is to shape the scientific literacy of society. Scientific literacy consists of scientific knowledge and skills that individuals need to master in decision making (Turiman, 2012). Therefore strengthening scientific literacy in each student as an individual is very important.

Scientific literate individuals are able to use scientific knowledge, identify questions, and draw evidence-based conclusions on issues related to nature and technology through human activities. Individuals can solve problems using scientific concepts obtained in the educational aspect to be creative in creating technology so that students can make the right decisions (Aprido, 2020).

So that the measurement of scientific literacy is used to determine the quality level of science education and the level of scientific literacy of students. One that affects students' scientific literacy skills is the teacher (Rubini, 2016). It is important to measure scientific literacy as a material for government evaluation in improving the quality of education. Students who are literate in science literacy are expected to be able to become innovative individuals and have high competitiveness. The reality of the field is used as a guideline for the government and teachers and encourages learning activities with scientific literacy.

Learning science must be holistic based on attitudes, knowledge, and skills to solve various problems (Khasanah, 2017). Through this, students must be able to respond to how to learn Science appropriately. This is in accordance with the opinion which states that science learning must equip teachers with professional knowledge (Putra, 2016). The formulation of the research problem is how the profile of students' scientific literacy skills is seen from aspects of knowledge, competence, and cognitive and what factors affect students' scientific literacy skills? The purpose of this study was to determine the profile of students' scientific literacy seen from aspects of knowledge, competence, and cognitive and to describe the factors that affect students' scientific literacy skills. 


\section{RESEARCH METHOD}

A research framework is provided to explain this research method. This method helps develop the quality of further learning in developing effective learning designs (Hjh, 2012). There are several steps in the research process. The research method describes the sample, the instruments used.

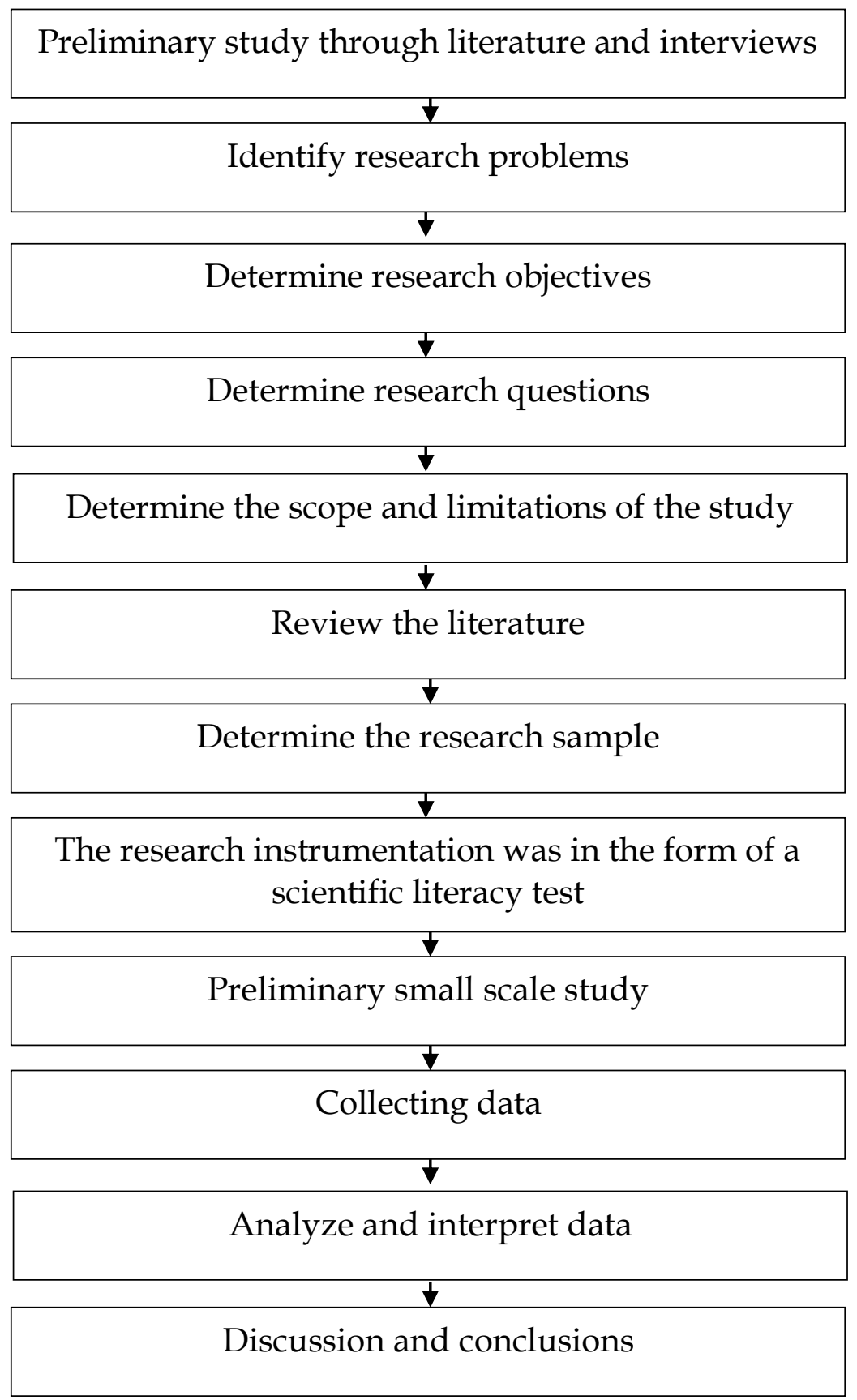

Figure 1. Flowchart of research procedure.

The research was conducted on 72 students at State Junior High School of 32 Surabaya study used a quantitative descriptive method because the data collection methods were preliminary studies, hypotheses, experiments, data analysis, and conclusions. The research was conducted on 72 students of SMP Negeri 32 Surabaya in odd semesters. Sampling was done randomly to 72 students in grade 9 . The study used 
a quantitative descriptive method because the data collection methods were preliminary studies, hypotheses, experiments, data analysis, and conclusions. The scientific literacy test has been tested in the limited trial class so that the validity and reliability test results are obtained. The validity test uses the pearson correlation test SPSS 22.0 with a valid category if it has a significance value of the pearson correlation $r$ count $>$ r table (0.3291) and sig. 2 tailed $<0.05$ (Ulfah, 2020). The results of the validity test of a total of 25 scientific literacy tests were 20 scientific literacy tests in the valid category, while 5 other questions were categorized as invalid. The reliability test used the Cronbach's alpha SPSS 22.0 test. The alpha value category shows an increase from 0.517 to 0.675 in the reliable category (Md Ghazali, 2016). The reliability test result of the science literacy test is 0.814 so it has a reliable category to be used several times.

This study did not use special treatment for the experimental class or the control class. Research reports use measurements, calculations using formulas, and data (Appelbaum, 2018). Material about scientific literacy related to diet and chronic diseases. The sample represents all grade 9 students who have studied dietary material science and chronic disease in grade 8 .

Research instruments to measure the profile of students' scientific literacy skills in the form of student response questionnaires and scientific literacy tests. The student response questionnaire contains indicators of the feasibility of learning science with four scales which are then converted into a Likert scale. The scientific literacy test instrument consists of 20 multiple choices that have been validated by two science lecturers at the State University of Surabaya and one science teacher at SMP Negeri 32 Surabaya. Science literacy test questions contain aspects of competence, knowledge aspects, competency aspects, and cognitive aspects according to the scientific literacy indicators proposed by Fives (2014).

Table 1. Indicators of science literacy competence.

\begin{tabular}{llll}
\hline \multicolumn{1}{c}{ Competence } & \multicolumn{2}{c}{ Scientific Competency Indicators } \\
\hline $\begin{array}{l}\text { Competency 1: } \\
\text { Explain phenomena scientifically }\end{array}$ & $\begin{array}{l}\text { 1. Explain scientific phenomena with } \\
\text { scientific knowledge. } \\
\text { Apply science knowledge in life. }\end{array}$ \\
\hline $\begin{array}{l}\text { Competency 2: } \\
\begin{array}{l}\text { Evaluating and designing } \\
\text { investigations }\end{array}\end{array}$ & $\begin{array}{l}\text { 2. } \\
\text { 3. Interpret basic statistics (eg data, graphic } \\
\text { patterns, and / or simple calculations). }\end{array}$ \\
\hline $\begin{array}{l}\text { Competency 3: } \\
\text { Interpret data and evidence scientifically }\end{array}$ & 4. Make the right conclusions. \\
\hline
\end{tabular}

After the data is obtained, then testing is carried out. The data obtained were in the form of quantitative data in the form of students' responses to the science literacy variable and science literacy mastery scores. Quantitative data were analyzed and described to draw conclusions on the relationship between scientific literacy and student response questionnaires. Calculating the relationship used Karl Pearson's correlative test. 


\section{RESULTS AND DISCUSSION}

Science literacy skills of students of SMP Negeri 32 Surabaya were measured by means of a scientific literacy test instrument. The test instrument consists of 20 objective questions with knowledge aspects, competency aspects, and cognitive aspects.

Table 2. Student science literacy score.

\begin{tabular}{lc}
\hline \multicolumn{1}{c}{ Criteria } & Results \\
\hline High score & 80.00 \\
\hline Low score & 30.00 \\
\hline Average score & 60.69 \\
\hline Percentage of students meeting the minimum completeness criteria & $66.67 \%$ \\
\hline The percentage of students who do not meet the minimum completeness criteria & $33.33 \%$ \\
\hline
\end{tabular}

Table 3. Recapitulation of measurement results based on science literacy competence.

\begin{tabular}{lccc}
\hline \multicolumn{1}{c}{ Science Literacy Indicators } & $\begin{array}{c}\text { Question } \\
\text { Number }\end{array}$ & $\begin{array}{c}\text { Number of } \\
\text { Questions }\end{array}$ & $\begin{array}{c}\text { Percentage of } \\
\text { Achievement (\%) }\end{array}$ \\
\hline $\begin{array}{l}\text { Explain scientific phenomena with } \\
\text { scientific knowledge }\end{array}$ & $8,12,14,16$ & 4 & 58.33 \\
\hline Apply science knowledge in life & $\begin{array}{c}4,5,9,10,11, \\
18\end{array}$ & 6 & 60.19 \\
\hline $\begin{array}{l}\text { Understand basic statistics (e.g. graphic } \\
\text { patterns and simple calculations) }\end{array}$ & $\begin{array}{c}3,6,13,19,20 \\
\text { Make the right conclusions }\end{array}$ & 5 & 58.33 \\
\hline \multicolumn{2}{c}{ Average competency aspects } & 5 & 65.56 \\
\hline
\end{tabular}

Table 4. Recapitulation of measurements based on cognitive aspects.

\begin{tabular}{llcc}
\hline \multicolumn{1}{c}{ Request } & \multicolumn{1}{c}{ Question Number } & $\begin{array}{c}\text { Number of } \\
\text { Questions }\end{array}$ & $\begin{array}{c}\text { Percentage of } \\
\text { Achievement (\%) }\end{array}$ \\
\hline Low & $8,9,14,16$ & 4 & 61.11 \\
\hline Moderate & $1,2,4,5,6,10,11,12,17,19,20$ & 11 & 62.63 \\
\hline High & $3,7,13,15,18$ & 5 & 56.11 \\
\hline \multicolumn{2}{c}{ Average cognitive aspects } & & 59.95 \\
\hline
\end{tabular}

Table 5. Recapitulation of Measurements Based on Aspects of Knowledge

\begin{tabular}{llcc}
\hline Aspects of Knowledge & Question Number & $\begin{array}{c}\text { Number of } \\
\text { Questions }\end{array}$ & $\begin{array}{c}\text { Percentage of } \\
\text { Achievement (\%) }\end{array}$ \\
\hline Content & $8,9,10,12,14,16$ & 6 & 57.87 \\
\hline Procedural & $2,4,5,13,19,20$ & 6 & 62.04 \\
\hline Epistemic & $1,3,6,7,11,15,17,18$ & 8 & 61.81 \\
\hline \multicolumn{4}{c}{ Average aspects of knowledge } \\
\hline
\end{tabular}

Table 5. Recapitulation of measurements based on aspects of context.

\begin{tabular}{lccc}
\hline \multicolumn{1}{c}{ Aspects of Context } & $\begin{array}{c}\text { Question } \\
\text { Number }\end{array}$ & $\begin{array}{c}\text { Number of } \\
\text { Questions }\end{array}$ & $\begin{array}{c}\text { Percentage of } \\
\text { Achievement (\%) }\end{array}$ \\
\hline Personal - health and disease & $6,7,9,11,12,14$ & 6 & 62.96 \\
\hline Local - health and disease & $1,4,5,13,17,20$ & 6 & 62.50 \\
\hline Local - natural resources & $2,3,15,19$ & 4 & 60.42 \\
\hline Global - health and disease & $8,10,16,18$ & 4 & 54.86 \\
\hline \multicolumn{2}{c}{ Average aspects of context } & & $\mathbf{6 0 . 1 9}$ \\
\hline
\end{tabular}


The result is $66.67 \%$ of students meet the minimum completeness criteria (KKM) and $33.33 \%$ of students do not meet the minimum completeness criteria (KKM). Since studying in elementary school to junior high school, students have obtained science content. However, for $66.67 \%$ of these students, there could be misconceptions in the content tested by the researcher. In addition, students have not been able to link certain disciplines with other disciplines so that the learning experience is less contextual. Whereas $33.33 \%$ of students understand the theory based on student learning experiences and apply the content correctly, but their understanding is limited to certain questions and it is difficult to link the concepts received into the answers.

The results showed that 48 students met the minimum completeness criteria and 24 students did not meet the minimum completeness criteria. Science literacy skills at SMP Negeri 32 Surabaya are moderate with the average percentage of competency aspects of 60.60 , cognitive aspects of 59.95, knowledge aspects of 60.57 , context aspects of 60.19 of the total number of students. The mean scientific literacy profile for all aspects is presented in Figure 1.

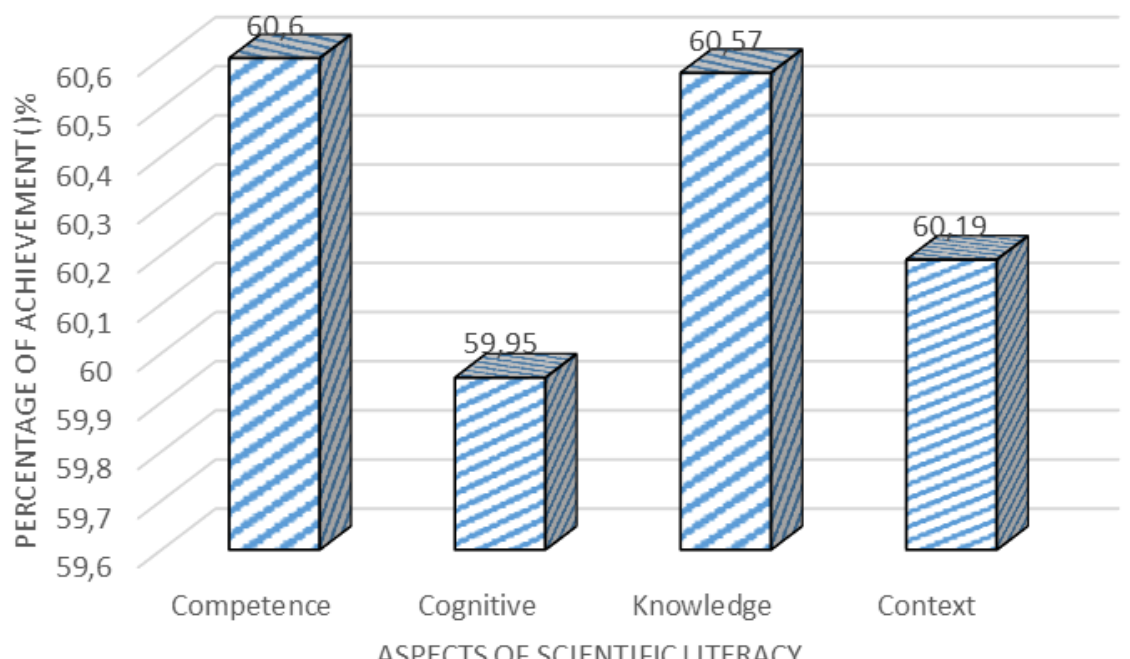

Figure 1. Profile of students' scientific literacy from the aspects of competence, cognitive, knowledge, and context.

The percentage of all aspects is above $50 \%$ of the total number of students. The mean value is above $50 \%$ due to the refraction of the 7,8 , and 9 grade "literacy" programs. The refraction program is carried out every day with a duration of 30 minutes. One of these factors has an effect on the field of science in increasing scientific literacy. As many as 48 students were able to understand, apply, and analyze concepts in integrating contextual life, but still had misconceptions. As many as 24 students have limited understanding and difficulty in explaining the knowledge they have acquired. Students' attitudes correlate with scientific literacy skills.

The factors that cause the low level of scientific literacy come from internal and external factors.Internal factorswhich affects consists of interest in science, motivation in literacy, attention to learning outside and inside the classroom, readiness to learn before learning. External factors consisting of factors in the teaching method of science literacy teachers, teachers' understanding of indicators of scientific literacy, classroom facilities, and peers. 
The results of the scientific literacy test were analyzed to describe the aspects of scientific literacy in detail. The recapitulation of measurement results based on the scientific literacy indicators in table 3 states that the highest average value is $65.56 \%$ in making correct conclusions. While the lowest score was $58.33 \%$ in explaining scientific phenomena with scientific knowledge and understanding basic statistics (eg graphic patterns and simple calculations).

Based on the research results, it is known that students have the ability to make conclusions correctly, but it is still difficult to explain phenomena based on scientific knowledge and understand statistics such as graphs and simple calculations. Through students' learning experiences about the world of science, students have read theories related to science, but students have their own understanding in understanding so that there are misconceptions and cannot explain concepts correctly (Soeharto, 2019).

Literate individuals need to have access to various learning resources that support scientific literacy. Students of SMP Negeri 32 Surabaya have only one learning resource that is used as a guideline, namely the Kemendikbud textbook. The textbooks are lent out for one level of education, then returned to the library when students advance to the level. However, interviews from students and teachers stated that the textbook competency test was not optimal in developing the character of literate students.

The recapitulation results of measuring the cognitive aspects show that the demand for low and medium cognitive aspects has almost the same average value, but is higher than the demand for high cognitive aspects. The highest average score in the moderate cognitive aspect was $62.63 \%$, while the lowest average score was on the high cognitive aspect of $56.11 \%$. Low ability to analyze high difficulty level questions tests knowledge that is not common to most students. Students are less able to analyze complex information or data; evaluating evidence; show evidence from various sources (Pahrudin, 2019). Cognitive demand is reaching the highest score because most students are able to apply conceptual knowledge to explain phenomena; choosing a procedure that involves two or more steps; organizing data; interpret a simple data set or graph.

The results of the recapitulation of the measurement of the aspects of knowledge show that the aspects of procedural and epistemic knowledge have almost the same average value, but higher than the aspects of content knowledge. The highest average score in the procedural knowledge aspect was $62.04 \%$, while the lowest average score was in the content knowledge aspect of $57.87 \%$. Based on these results, most students know the knowledge of scientific procedures or methods used to gain knowledge and through scientific procedures students can justify the hypotheses put forward by science. The low aspect of student content knowledge is related to students' low understanding of the facts, concepts and theories that make up scientific knowledge which includes knowledge about nature and technology. Students do not apply the theory learned in everyday life. In addition, students are not strong enough to remember appropriate knowledge in certain situations and do not use it to provide an explanation of the phenomena that occur.

Factors that can improve scientific literacy skills are literacy related to scientific issues related to identifying, analyzing, and making decisions to solve problems (Winarni, 2019). Scientific literacy requires three forms of scientific knowledge in the form of personal, local, and global contexts (Fakhriyah, 2017). The score for personal context aspects (health and disease) has almost the same score for aspects of the local 
context (health and disease), where the two aspects have a difference of 0.46 . Both aspects deal with issues with practices affecting health and disease. Students are enthusiastic about literacy which refers to the needs of human life to survive everyday. Students as individuals in the community live as consumers of technology and science products. This product is connected with water, food, and health as basic human needs. The level profile of the context aspect can be used as a basis for policy makers in the form of cleaning the family and school environment in rotation, environmental exploration related to food welfare, and activities to bring nutritious food supplies from home.

Students are able to identify problems and explain some chronic diseases caused by wrong diet. The author links health and disease issues to natural resources. Natural resource issues involve several aspects of the context, one of which is health and disease. The value of the aspects of natural resources and health is almost the same. This means that students can relate problems of food, health, disease with other concepts, namely natural resources.

The quality of education can be improved by marking a good literacy score, especially scientific literacy. Literacy scores are high if students from an early age can understand the cause and effect of natural phenomena by reading various literatures. However, students are not interested in reading sharing learning resources. In addition, parents do not get children used to reading, so they do not support literacy habits developed by schools.

The teacher has taught science thematic learning that is integrated with the environment, technology and society (Gathong, 2019). However, students have not been able to integrate their insights, they are still fragmented in a problem (Jurecky \& Matthew, 2012). One of the contributing factors is intelligence and interest. Students who are interested in science can answer well, while students who are interested in non-science subjects have difficulty. The difficulties experienced are in the form of identifying problems, processing data, and making decisions (Arifin, 2017).

Improved communication and problem solving can be obtained from reading, writing, and reviewing journals so that they can increase scientific literacy (O'toole, 2020). Scientifically and technically, the factors causing the high and low level of individual literacy are intellectual capacity which includes attitudes, social characteristics, levels of reasoning, and integrating various disciplines (Purwani, 2018).

Questionnaires and learning strategies on 20 questions are 3 indicators of attitude aspects. The questionnaire consists of yes and no answers. Then the scores taken from these students are correlated with scientific literacy skills to determine the relationship between scientific literacy and students' attitudes towards science and their teaching and learning strategies. Recapitulation and scientific literacy with questionnaire scores are presented in Table 5.

Table 5. Recapitulation of scientific literacy and the relationship of scientific attitudes.

\begin{tabular}{cc}
\hline Attitude Indicator & Correlation value \\
\hline Interest in science & $-0,556$ \\
\hline Scientific approach to research & 0.540 \\
\hline Environmental awareness & 0.777 \\
\hline
\end{tabular}


Table 5 illustrates the relationship between student response questionnaire scores and the scores for scientific literacy skills. Correlation test using Pearson test. Wang (2012) stated category of very weak correlation (0.00-0.199), weak correlation (0.20$0.399)$, moderate correlation $(0.40-0.599)$, strong correlation $(0.60-0.799)$, very strong correlation (0.80-1.0).

Student response questionnaires correlate with scientific literacy skills. The attitude questionnaire consisted of three variables, namely interest in science, a scientific approach to research, and environmental awareness. The indicator of the attitude of interest in science obtained a value of -0.556 . If the correlation result is positive, it means that the correlation between variables is unidirectional and if the correlation result is negative, then the correlation between the opposite variables (Abu Bakar, 2019). There is a negative relationship between the attitude of interest in science and scientific literacy skills. This means that scientific literacy-based learning treatment does not increase students' interest in science. Research focuses only on aspects of the context of health, food, chronic disease, and natural resources. So that it allows science literacy-based learning to less increase students' interest in science. However, students are open and confident in science and confident to answer questions. Holden (2012) says that selfconfidence affects scientific literacy. Teachers need to provide an open environment for students to express their knowledge and feelings so as to create interest in science. If the teacher can create this, then the teacher can develop student creativity.

The attitude indicator for the scientific approach to research obtained a correlation value of 0.540 with a moderate correlation category. The scientific attitude to research towards science affects decision making that is reasonable and appropriate (Jho, 2014). Science literacy trains students to think and act systematically. Thus, constructivism studies, literacy skills, problem solving skills are important for teachers to develop. The self-awareness attitude indicator obtained a correlation value of 0.777 with a strong correlation category. There is a positive relationship between self-awareness and scientific literacy skills (Genç, 2019). The attitude of the scientific approach and selfawareness are related. With the development of studies, students will be more confident and concerned about implementing knowledge for society.

The most efficient way to improve scientific literacy of 15 year old students is by "spending time studying", encouraging students to be active in experimenting (Anagün's, 2011). It is very important for teachers to apply inquiry-based learning in the teaching and learning process to improve scientific literacy. Science literacy increases students 'confidence in communicating, listening to friends, and commenting on friends' opinions. Commenting on the opinions of other friends trains students' attitudes to be responsible and aware of problems that occur in the environment. Students improve scientific literacy by doing different tasks, so that students can recognize the interests of certain fields. It is very important for teachers to implement various kinds of learning strategies so that they support the character's attitude of confidence to make decisions.

These various skills serve to improve scientific literacy and make students have the character of a curious attitude towards science, self-confidence, literacy, problem solving, critical thinking, and being able to communicate. If the goals are achieved, it will be easy for students as individuals to solve related issues that occur in the personal, community, or global environment. 
The results of the study stated that Science literacy profile of students aged 15 years (SMP) based on aspects of knowledge, competency aspects, cognitive aspects, and low context aspects. The literacy profile can be improved with a science study program. Increased scientific literacy, academic achievement and learning outcomes will increase and be meaningful. Kusumastuti (2019) states that scientific literacy has a positive effect on student development and planned systematic studies. Therefore, aspects of scientific literacy must be improved so that student goals can be achieved.

Widiyanti (2015) states that scientific literacy-based learning tools can make students literate so that they can improve their learning outcomes. Previous studies have shown student-centered learning methods have the advantage of increasing the depth of understanding of knowledge (Hanewicz, 2017). Learning strategies that can be applied by teachers to encourage scientific literacy include flipped classrooms (Jdaitawi, 2019), inquiry (Innatesari, 2019), problem-based (Yuliati, 2018), and others.

\section{CONCLUSIONS}

The scientific literacy ability of students at State Junior High School of 32 Surabaya is in the low category because the science literacy ability score is $\leq 75$. It needs a lot habituation, strategies, and appropriate learning methods to improve scientific literacy skills. Teachers can develop student skills in terms of competency, cognitive, knowledge, and scientific literacy contexts. Teachers need to provide access to learning resources from various literary sources, including browsing information via the internet. Students need to be trained to be literate, hone critical and creative thinking, be competent in making decisions to solve problems, and communicate.Students as a community need support from all parties in order to be literate, not only at State Junior High School of 32 Surabaya but students in all corners of Indonesia. Further research is needed to analyze why students' scientific literacy is low. Teachers must familiarize students with scientific literacy-based test instruments such as those modeled by PISA, so that they can compete with students from other countries and are able to make the right decisions in solving scientific problems.

\section{REFERENCES}

Aberšek, Metka Kordigel., Kosta Dolenc., Andrej Flogie., and Ana Koritnik. 2015. New natural science literacies of online research and comprehension: To teach or not to teach. Journal of Baltic Science Education, 14(4), 460-473.

Bakar, A., Hassan, M. N., Zakaria, A., \& Halim, A. A. (2019). Pearson's correlation coefficient analysis of non-invasive jaundice detection based on colour card technique. Journal of Physics: Conference Series, 1372(1). https:/ / doi.org/10.1088/1742-6596/1372/1/012012

Anagün, g.S. (2011). The impact of teaching-learning process variables to the students' scientific literacy levels based on pisa 2006 results. Education and Science, 36(162), 84-102.

Appelbaum, M., Cooper, H., Kline, R. B., Mayo-wilson, E., Nezu, A. M., Rao, S. M., \& Clinic, C. (2018). Correction: Journal article reporting standards for quantitative research in psychology: The APA publications and communications board task force report. American Psychologist, 73(1), 3-25.

Simamora, A. B., Widodo, W., \& Sanjaya, I. G. M. (2020). Innovative learning model: improving the students' scientific literacy of junior high school. IJORER : International Journal of Recent Educational Research, 1(3), 271-285. https://doi.org/10.46245/ijorer.v1i3.55 
Archer-bradshaw, R. E. (2014). Demystifying scientific literacy: Charting the Path for the 21st Century. Journal of Educational and Social Research, 4(3), 165-172.

https://doi.org/10.5901/jesr.2014.v4n3p165

Argina, W, A., Mitra, Delsi., Ijabah, Nur., \& Setiawan, R.. (2017). Indonesian PISA Result : What Factors And What Should Be Fixed?. The 1st Education And Language International Conference Proceedings Center for International Language Development of Unissula. P.69-79.

Arifin, L., \& Sunarti, T. (2017). The improvement of students' scientific literay through guided inquiry learning model on fluid dynamics topic. Jurnal Penelitian Fisika Dan Aplikasinya (JPFA), 7(2), 68-78. https://doi.org/10.26740/jpfa.v7n2.p68-78

Fakhriyah, F., Masfuah, S., Roysa, M., Rusilowati, A., \& Rahayu, E. S. (2017). Student's science literacy in the aspect of content science? Jurnal Pendidikan IPA Indonesia, 6(1), 81-87. https://doi.org/10.15294/jpii.v6i1.7245

Fives, H., Huebner, W., Birnbaum, A. S., \& Nicolich, M. (2014). Developing a Measure of Scientific Literacy for Middle School Students. Science Education, 98(4), 549-580. https://doi.org/10.1002/sce.21115

Garcia-Santillan, A., Moreno-Garcia, E., Carlos-Castro, J., Zamudio-Abdala, J. H., \& GardunoTrejo, J. (2012). Cognitive, affective and behavioral components that explain attitude toward statistics. Journal of Mathematics Research, 4(5). https://doi.org/10.5539/jmr.v4n5p8

Gathong, S., \& Chamrat, S. (2019). The implementation of science, technology and society environment (STSE)-based learning for developing pre-service general science teachers' understanding of the nature of science by empirical evidence. Jurnal Pendidikan IPA Indonesia, 8(3), 354-360. https:// doi.org/10.15294/jpii.v8i3.19442

Gen, M. (2015). The effect of scientific studies on students' scientific literacy and attitude. Ondokuz Mayıs Üniversitesi Eğitim Fakültesi Dergisi, 34(1), 141-152. https://doi.org/10.7822/omuefd.34.1.8

Hanewicz, C., Platt, A., and Arendt, A. (2017). Creating a learner-centered teaching environment using student choice in assignments. Distance Education, 38, 273-287. doi: 10.1080/01587919.2017.1369349

Hjh, D., Awang, T., \& Hamid, H. (2012). Implementation of an online collaborative learning through grid portal implementation of an online collaborative learning through grid portal technology. January. 3rd International Conference on e-Education, e-Business, e-Management and e-Learning IPEDR, 27, 35-42.

Holden, I. I. (2012). Predictors of students'attitudes toward science literacy. Communications in Information Literacy, 6(1), 107-123.

Innatesari, D. K., Sajidan, S., \& Sukarmin, S. (2019). The profile of students' scientific inquiry literacy based on scientific inquiry literacy test (ScInqLiT). Journal of Physics: Conference Series, 1227(1). https:/ / doi.org/10.1088/1742-6596/1227/1/012040

Irianti, Dewi. 2019. Tesis "Pengembangan perangkat pembelajaran IPA terpadu berbasis karakter untuk meningkatkan kemampuan berpikir kritis dan literasi sains peserta didik SMP." Yogyakarta: Universitas Negeri Yogyakarta.

Jampel, N., Fahrurrozi., Artawan, G., Widiana, W., Parmiti, P. D., Hellman, J. (2018). Studying natural in elementary school using nos-oriented cooperative learning model with the NHT Type. Jurnal Pendidikan IPA Indonesia, 7(2), 138-146.

Jdaitawi, M. (2019). The effect of flipped classroom strategy on students learning outcomes. International Journal of Instruction, 12(3), 665-680. https:/ / doi.org/10.29333/iji.2019.12340a

Jho, H., Yoon, H. G., \& Kim, M. (2014). The relationship of science knowledge, attitude and decision making on socio-scientific issues: The case study of students' debates on a nuclear power plant in Korea. Science and Education, 23(5), 1131-1151. https://doi.org/10.1007/s11191-013-9652-z 
Jurecki, K., \& Wander, M. C. (2012). Science literacy, critical thinking, and scientific literature: Guidelines for evaluating scientific literature in the classroom. Journal of Geoscience Education, 60(2), 100-105.

Khasanah, Nur., Sajidan., Sutarno., Baskoro. 2017. Influence integrated science model and implamantation learning with the unity of science in basic biology course to increase critical thinking. International Conference on Science and Applied Science 2016. International Journal Scientific and Application Science: Conference Series, 1(2), 131-136.

Kusumastuti, F. A., Rombot, O., \& Ariesta, F. W. (2019). The effect of stem integration on primary school students' scientific literacy. International Journal of Scientific and Technology Research, 8(12), 1551-1553.

Laugksch, Rüdiger C. 2017. Scientific literacy: A conceptual overview. John Wiley \& Sons, Inc. in Science Education, 84(1): 70-94. DOI: 10.1002/(SICI)1098-237X(200001)84:13.0.CO;2-C.

Malik, R. S. (2018). Educational challenges in 21st century and sustainable development. Journal of Sustainable Development Education and Research, 2(1), 9-20.

Md Ghazali, N. H. (2016). A reliability and validity of an instrument to evaluate the schoolbased assessment system: a pilot study. International Journal of Evaluation and Research in Education (IJERE), 5(2), 148. https://doi.org/10.11591/ijere.v5i2.4533

O'toole, J. M., McKoy, K., Freestone, M., \& Osborn, J. A. (2020). 'Scientific literacy': An exercise in model building. Education Sciences, 10(8), 1-16. https://doi.org/10.3390/educsci10080204

OECD, 2018. Programme For international student assesment (PISA) result PISA 2018. OECD Publishing: Paris.

Purwani, L. D., Sudargo, F., \& Surakusumah, W. (2018). Analysis of student's scientific literacy skills through socioscientific issue's test on biodiversity topics. Journal of Physics: Conference Series, 1013(1). https:// doi.org/10.1088/1742-6596/1013/1/012019

Putra, MIS, Widodo, W., \& Jatmiko, B. (2016). Pengembangan materi pembelajaran sains inkuiri terpadu untuk meningkatkan keterampilan literasi sains calon guru MI Jurnal Pendidikan IPA Indonesia, 5(1), 83-93.

Rubini, B., Ardianto, D., Pursitasari, I. D., \& Permana, I. (2016). Identify scientific literacy from the science teachers' perspective. Jurnal Pendidikan IPA Indonesia, 5(2), 299-303. https://doi.org/10.15294/jpii.v5i2.7689

Soeharto, Csapó, B., Sarimanah, E., Dewi, F. I., \& Sabri, T. (2019). A review of students' common misconceptions in science and their diagnostic assessment tools. Jurnal Pendidikan IPA Indonesia, 8(2), 247-266. https://doi.org/10.15294/jpii.v8i2.18649

Turiman, P., Omar, J., Daud, A. M., \& Osman, K. (2012). Fostering the 21st Century Skills through Scientific Literacy and Science Process Skills. Procedia - Social and Behavioral Sciences, 59, 110-116. https://doi.org/10.1016/j.sbspro.2012.09.253

Ulfah, A. A., Kartono, K., \& Susilaningsih, E. (2020). Validity of content and reliability of interrater instruments assessing ability of problem solving. Journal of Research and Educational Research Evaluation, 9(1), 1-7. https://doi.org/10.15294/jere.v9i1.40423

Wang, H., Choi, I., Schmidgall, J., \& Bachman, L. F. (2012). Review of pearson test of english academic: Building an assessment use argument. Language Testing, 29(4), 603-619. https://doi.org/10.1177/0265532212448619

Widiyanti, F., Indriyanti, D. R., \& Ngabekti, S. (2015). The effectiveness of the application of scientific literacy-based natural science teaching set toward the students' learning activities and outcomes on the topic of the interaction of living organism and environment. Jurnal Pendidikan IPA Indonesia, 4(1), 20-24.

Widowati, A., Widodo, E., Anjarsari, P., Setuju. 2017. The development of scientific literacy throught nature of science (nos) within inquiry based learning approach. International Conference on Science and Applied Science 2017. IOP Conf. Series: Journal of Physics: Conf. Series 909 (2017) 012067, 1-7. Doi :10.1088/1742-6596/909/1/012067 
Winarni, E. W., Hambali, D., \& Purwandari, E. P. (2020). Analysis of language and scientific literacy skills for 4th grade elementary school students through discovery learning and ict media. International Journal of Instruction, 13(2), 213-222. https://doi.org/10.29333/iji.2020.13215a

Yuliati, L., Parno, P., Hapsari, A. A., Nurhidayah, F., \& Halim, L. (2018). Building Scientific Literacy and Physics Problem Solving Skills through Inquiry-Based Learning for STEM Education. Journal of Physics: Conference Series, 1108(1). https://doi.org/10.1088/1742$\underline{6596 / 1108 / 1 / 012026}$.

\section{${ }^{*}$ Yohana Saraswati (Corresponding Author)}

Postgraduate Program, Science Education

State University of Surabaya,

Jl. Lidah Wetan, Surabaya, East Java, Indonesia

Email: yohana.19003@mhs.unesa.ac.id

\section{Dr. Sifak Indana, M.Pd}

Postgraduate Program, Science Education

State University of Surabaya,

Jl. Lidah Wetan, Surabaya, East Java, Indonesia

Email: sifakindana@unesa.ac.id

\section{Dr. Elok Sudibyo, M.Pd}

Postgraduate Program, Science Education

State University Of Surabaya,

Jl. Lidah Wetan, Surabaya, East Java, Indonesia

Email: eloksudibyo@unesa.ac.id 